\title{
HOW COULD RENEWABLE ENERGY RESOURCES BRIDGE THE GAP IN NIGERIA'S ENERGY SECTOR?
}

\author{
Gift Nwabueze ${ }^{* 1}$ 四 \\ ${ }^{* 1}$ Emerald Energy Institute, University of PortHarcourt, Nigeria \\ DOI: https://doi.org/10.29121/ijetmr.v7.i11.2020.804
}

Article Citation: Gift Nwabueze. (2020). HOW COULD RENEWABLE ENERGY RESOURCES BRIDGE THE GAP IN NIGERIA'S ENERGY

SECTOR? International Journal of Engineering Technologies and Management Research, 7(11), 9-16. https://doi.org/10.29121/ijetmr.v7 .i11.2020.804

Published Date: 10 November 2020

Keywords:

Levellised Cost of Electricity

Carbon Pricing

Renewable Energy

Private Sector Investment

Fiscal Incentives

Nigeria

\begin{abstract}
This paper presents renewable energy resources development as a means of abating the shortfall in electricity generation in Nigeria. Levellized Bus-bar Cost Estimation method is used to carry out cost analysis of various power generation technologies by comparing their levellized costs. Carbon Emissions Pricing theory is also utilized to show that the cost per mega watt of renewable energy resources power plants can be comparable to their fossils counterpart when price is assigned to the emissions that result from using fossil fuels. Finally, government's participation in time bound renewable energy projects, as well as financial and fiscal incentives are identified as actions that will encourage private sector investments in renewable energy development, which has a stimulating effect on the larger economy.
\end{abstract}

\section{INTRODUCTION}

According to World Bank report (2015), Nigeria's population stands at about 182.2 million people with total energy consumption given as 108Mtoe as at 2011 (U.S. Energy Information Administration, 2014). Of this total consumption, $83 \%$ was from traditional biomass and waste, $16 \%$ from fossils and $1 \%$ from hydro energy source. Energy resources are consumed in Nigeria through the following forms; Transportation, Agriculture, Industrial, Electricity generation etc.

The conversion of energy resources to its usable form involves processes whose complexity depends on the energy use. Conversion of energy to electricity for instance will proceed from generation through transmission to distribution where it is actually consumed. Therefore, inadequate generation capacity will result in inadequate power supply to end users, resulting in constant outages, rationing load shedding and interruptions in supply by the power supplier.

Table 1, below shows the total power generation capacity for two randomly chosen weeks in December 2016 by Nigerian Electricity Regulatory Commission (NERC). The peak power generated hovered around 3500 to 4000 Mega watts (MW) of electricity available for the national grid. With total electricity consumption capacity in Nigeria hovering between 15000 - 30000 MW (Sambo, 2006), there exists a huge energy generation deficit in the Nigerian

(C) 2020 The Author(s). This is an open access article distributed under the terms of the Creative Commons Attribution License, which permits unrestricted use, distribution, and reproduction in any medium, provided the original author and source are credited. 
electricity supply market, thereby entrusting consumers with the job of generating more than $60 \%$ of their electricity needs through more expensive and unsustainable private sources.

Table 1: NERC Weekly Energy Watch for December 2016

\begin{tabular}{|c|c|c|}
\hline Weekly Energy Watch (December 2016) & Last Week Average & This Week average \\
\hline Energy Generated (MWh) & 83692 & 73718 \\
\hline Energy Sent Out (MWh) & 82404 & 72641 \\
\hline Peak (MW) & 3927 & 3456 \\
\hline Off-Peak (MW) & 2926 & 2384 \\
\hline Spinning Reserve (MW) & 19 & 16 \\
\hline Constrained (MW) & 3258 & 3868 \\
\hline Units (Available) & 83 & 79 \\
\hline Units (On Bars & 44 & 37 \\
\hline
\end{tabular}

Source: NERC website

The objective of this paper is to examine how renewable energy sources could bridge the gap in the Nigerian energy sector by providing alternative and additional power generation capacity to address the shortfall in power supply.

The scope of this paper is limited the use of renewable energy resources for electricity generation within the Nigerian energy industry. Other challenges facing the Nigerian power sector such as lack of adequate transmission and distribution infrastructure, inadequate metering, tariffs issues etc, will not be treated in this paper.

The approach to this work is to describe different renewable energy sources and show how these renewable resources plants are used for power generation. Also, because of the problem of intermittency associated with renewable energy electricity generation, renewable supplies alone may not be able to provide reliable electricity supplies all through the required period and will require additional generation plants within the power system, usually from non renewable resources. This paper further shows how renewable resources power plants can be combined with non-renewable energy resources power plants in a power system to result in optimum capacity utilization. Furthermore, the economical viability of renewable energy resources power plant will be proven by considering economics of electricity generation and the cost of carbon emissions.

\subsection{LITERATURE REVIEW}

This section presents a brief background of renewable energy resources and the potential for harnessing these resources in Nigeria and a review of some previous works and papers presented on the subject of renewable energy and its applications.

According to Gosh and Prelas (2009), Energy can be defined as the ability to perform work or generate heat. Energy resources must first be converted to usable forms such as mechanical, electrical or heat energy for it to impact positively on a people. They can be categorized as renewable and non renewable sources. A non renewable source is that which is not replaced continuously or undergoes very slow replacement process. Examples are fossils (petroleum, natural gas and coal), uranium and thorium while renewable sources can be replaced continuously within a very short time. Examples are solar energy, hydro and biomass. Renewable energy sources are derived directly or indirectly from the sun and possess the ability to provide additional generation capacity which is clean energy with zero emissions and environmental impacts and its development boosts economic activities around where it is located. Renewables Global Status Report (2007) identifies the most common renewable energy sources in Nigeria as Hydro and Biomass, with Wind and Solar only being deployed at a minute scale.

\subsection{HYDRO ENERGY}

Hydro power plant converts the kinetic energy of falling water such as waterfalls, dams or river to generate electricity. The kinetic energy is first converted to mechanical energy by turning a turbine blade and this is in turn converted to electricity through a generator. Hydro power source have been identified to be the highest source of power generation worldwide among all the renewable energy sources by Gauss and Prelas (2009), and has a 
Gift Nwabueze

worldwide growth rate of $1.6 \%$ annually, contributing 406 billion KWh of electricity between 1994 and 2004 . In Nigeria, Kainji was the first hydro power station and was built in 1968 with a capacity of 760 MW and later expanded to 1150 MW. Jebba and Shiroro were built in 1984 and 1990 with and installed capacity of 570 MW and 600 MW respectively (Zarma, 2006). Also, according to World Bank sources, compared to about 38\% of total electricity generated in 1999 in Nigeria, hydropower sources accounted for 22\% of total electricity power generated in 2011. Meanwhile, electricity generation from natural gas source grew from 52\% in 1999 to 63\% in 2011 (Trading economics, 2017). This implies that hydropower was the main source of electricity generation during the early years of Nigeria's independence but was then neglected since the 1990s and more attention was paid to thermal power plants.

\subsection{SOLAR ENERGY}

This is basically energy derived from the sun. Solar panels are made of PV cells which when in contact with light from the sun, particles (photons) containing energy constantly strike the P-N junction area of the cell and are absorbed. These photons (carrying energy from the sun) enough energy for the electrons to overcome the potential barrier of the electric field created in the junction and flows across the junction to power electrical appliances. Although solar power plants may require higher initial cost and larger space for its installation, in the long run it becomes cheap due to its very low maintenance cost. Nigeria has a very large land mass and that takes care of the space constraint with this technology. Other advantages include noiseless operation and zero emissions to the environment. Nigeria has not really tapped into the great potentials it possesses with solar power. From NIMET's info sheet, Nigeria possess an average annual daily sunshine of 6.25 hours and a daily solar radiation of about $3.5 \mathrm{KWm} 2 /$ day in the coastal areas with about $7.0 \mathrm{KWm} 2 /$ day in the northern boundary. Also, with about 4909.212KWh of energy from the sun, which is equivalent to about 1.082 million tonnes of oil, Nigeria can produce about 4000 times and 13000 times the energy produced from the daily production of crude oil and gas respectively. It is also estimated that when one percent of Nigeria's land area is covered with a solar technology of five percent efficiency, about $333,480 \mathrm{MW}$ of electricity may be produced at about $26 \%$ capacity factor. This electricity generation capacity will be more than enough for the country up to 2050, and that will conveniently provide $11 \%-13 \%$ economic growth as envisioned in vision 20:20:20 (Globe Power Services limited, 2016).

\subsection{BIOMASS AND BIOFUEL}

Biomass involves vegetation from plants, trees, stems, weeds and waste and they present diverse opportunities for countries of the world to generate heat, electricity and for transportation. While biofuel is used for transportation, biopower is used for electricity generation. Although biomass contributes nearly 1067 Mtoe of worldwide energy use, only about $2 \%$ of that is used for electricity generation (Gauss and Prelas, 2009). Also, according to International Energy Agency reports, sub-Saharan Africa is the largest consumer of biomass (about $86 \%$ of world use) but this is mainly used for cooking and heating. In India, about $302 \mathrm{MW}$ of electricity has been generated from biomass through various projects (MNRE, 2009). Diji (2013) splits the technology for converting biomass to electricity as either through dedicated use of biomass (direct combustion or gasification) or by co-firing biomass with fossils plant.

\subsection{WIND ENERGY}

A Wind turbine is used to convert kinetic energy from the wind into mechanical energy which is in turn converted into electrical energy. A wind farm is a collection of wind turbines in the same location for the generation of electricity in large quantity. Because wind flow is not always steady and consistent just like solar energy, several technologies are applied to store the excess energy during high winds. The UK research center reviewed several studies on wind and other renewable and concluded that intermittency is not a challenge to renewable energy development. On grid wind turbine can add to the total grid transmission while off grid turbines can be used to provide electricity for remote locations and rural dwellers. Nigeria as a country has not tapped into its huge potential for wind energy but other countries are benefiting from this natural resource to develop very clean energy. New analysis of figures from Carbon Brief has shown that the UK generated more electricity from wind than it did from coal during 2016 and CO2 emission in the same year fell by around 20\%. 
Also, in 2009, wind energy provided 71 billion KWh of electricity which was about $1.8 \%$ of the total US electricity generation. Similarly, Denmark which is $9^{\text {th }}$ in the world ranking for wind generated electricity generates $20 \%$ of its electricity from wind (Gauss and Prelas, 2011). Wind farms should be located at the top of hills, shorelines or open plains. These locations have less wind interference and noise disturbance to consumers.

\subsection{MERIT ORDER DISPATCHING}

Merit order provides a form of ranking of electrical energy generation sources according to the order of their cost. The ranking is done such that plants with lower marginal costs are first powered on before the plants with higher marginal cost. Because of the problem of intermittency of supply, renewable energy power plants do not follow normal merit order dispatch pattern. They have to be dispatched as soon as they are produced. But because renewable plants have the lowest marginal costs (zero fuel cost), they tend to reduce the overall price of the tariffs to be paid for by the electricity consumers. According Frank et al (2007), the introduction of Renewables plant in Germany's power system led to more than $10 \%$ reduction in the cost of electricity to consumers.

\subsection{SCREENING CURVE ANALYSIS}

This is a plot of levellized cost on the vertical axis versus capacity factor on the horizontal axis.

The approach is to plot the screening curves for different power plants and based on the steepness of the plot, the right choice of power plant for a given type of load can be chosen. Crossover point shows the capacity factor at which the Levellized cost of operating both plants become equal. Screening curve can be plotted with Load duration curve to give a way to achieve a mix of power generation plants within a power system for optimal performance. By determining the levellized cost and average capacity factor, screening curve can show the capacity utilization at which the seemingly higher levellized cost for renewable sources powered plants becomes equal to the levellized cost for fossil powered plants.

\subsection{EMPIRICAL REVIEW}

Simonyan and Fasina (2013), in their paper titled "Biomass resources and Bioenergy potentials in Nigeria", estimated that Nigeria has the ability to produce 2.01 EJ (49.97Mtoe) of energy derived from 168 million tons of agricultural wastes in one year. They stated that these residues which are currently being mostly burnt-off could be harnessed to enhance energy supply in Nigeria. They further identified the different sources of biomass in Nigeria as agricultural crops residue, aquatic weeds, algae, urban wastes, animal wastes and forest resources and concluded that the conversion of biomass to energy will be of great benefit to the country given the huge biomass resources available and urged the federal government to include biomass development to the ongoing renewable energy programs and policies.

Zarma (2006) identified the huge hydro potential in Nigeria as indicated by large rivers, small rivers and multiple river basins being developed and that these rivers are distributed all over the country. He identified over 278 unexploited small hydro sites with potential amounting to about $734.3 \mathrm{MW}$. The paper which aimed to elucidate the possible contribution of small hydro development to the energy sector, concluded by explaining all the implicit and explicit benefits of developing small hydro sources such as improved availability and quality of power supply, industrial and economic development, clean power development, economic growth and employment, public services, accessibility, benefits for women and improved quality of life.

Finally, In his paper titled "Economics of Renewable energy", Heal (2009) Identified four major factors that affects the development of renewable energy sources as Oil price, Carbon prices, Cost of capital and Regulatory regime. Because renewable energy projects would normally require large fixed cost, low or no variable cost and low marginal cost, huge capital requirement is an impediment. He stated that cost comparison between fossils and renewable sources is best done in terms of average cost. Also, by considering cost of fuel and cost of carbon which applies to fossils, estimating average cost as Levellized Social Cost of Electricity (LSCOE) is imperative. Finally, he concluded that the intermittency of supply for wind and solar resources resulting in a very low capacity factor limits the markets in which wind and solar can compete in, thereby making a case for carbon capture technologies in coal fired plant and nuclear fired plants. 


\section{MATERIALS AND METHOD}

This section analyzes the economics of electricity generation, in order to highlight the cost associated with using each energy source. The idea behind this analysis is to prove the economic viability of renewable energy technologies and show how to best select the right combination of power generation technologies in order to most effectively utilize renewable energy resources in solving Nigeria's power sector challenge. It also considers the social cost of carbon emissions as an additional cost to the use of fossils plant which further reduces the difference between the cost of operating renewable energy power plant and fossils power plant.

\subsection{METHODOLOGY}

Because electricity generation projects are highly capital intensive, a proper cost analysis is required to determine which technology is required for electric power generation within a given power system. Subhes (2011) highlights two methods of carrying out this analysis; the levellized bus-bar cost method and the screening curve analysis method.

\section{Levellized bus-bar cost}

This is done by expressing different annual cost estimate as a single constant value. Because power plants are designed to operate for several years, the present value is taken into consideration.

Ie $\quad \mathrm{PV}=\mathrm{A} \times \mathrm{PVF}$

Where; $P V \rightarrow$ Present value, $A \rightarrow$ Present annual cost and $\mathrm{PVF} \rightarrow$ Present value factor.

Therefore;

Levelized cost LC $=$ PV x CRF. (CRF $\rightarrow$ Capital recovery factor; which is obtained from available standard CRF table).

The calculations are carried out for all fuel cost, operation cost and maintenance cost. The total owning cost is divided by the annual electricity generation per year to arrive at the unit cost of the electricity technology. Table 2 shows the levellized cost for different electricity generation plants as researched by EPRI (2009), higher levellized cost is noticed for renewable energy sources compared to their non-renewable counterparts. Some suggested solutions to this cost constraint are highlighted in the 'Discussions' section of this chapter.

Table 2: Levellized cost of electricity generation from different sources

\begin{tabular}{|c|c|c|}
\hline Technology Description & $\begin{array}{c}\text { Cost in } 2015(2008 \text { constant } \\
\$ / \mathrm{MWh}\end{array}$ & $\begin{array}{c}\text { Cost in 2025 (2008 constant } \\
\$ / \mathrm{MWh})\end{array}$ \\
\hline Super critical pulverized coal & 66 & $86-101$ \\
\hline Integrated gasification combine cycle & 71 & $78-92$ \\
\hline Combustion turbine combined cycle & $74-89$ & $74-81$ \\
\hline Nuclear & 84 & 82 \\
\hline Wind & 99 & 77 \\
\hline Biomass circulating fluidised bed & $77-90$ & $225-290$ \\
\hline Solar thermal trough & $225-290$ & 456 \\
\hline Solar PV & 456 & \\
\hline
\end{tabular}

Source Subhes (2011)

\subsection{COST OF CO2 EMISSION}

World Bank program on pricing carbon identifies two main ways of pricing carbon; Emissions trading scheme and Carbon taxes. In emissions trading scheme, industries with low carbon emissions are allowed to sell the extra allowance to industries that exceed a capped emission value. By creating demand and supply for the emissions 
allowance, a price is set for carbon emissions. Carbon tax method on the other hand prices carbon by setting a tax rate based on the carbon content of fossil fuels. Other more advanced ways of pricing carbon are through fuel taxes, fuel subsidy removal, and through regulations that incorporate a social cost of carbon. The table below shows Social Cost of Carbon estimates as agreed for the UK policy analysis.

Table 3: Social cost of carbon estimate.

\begin{tabular}{|c|c|c|}
\hline SCC Estimates - Year of Emission & & \\
\hline Existing UK SCC (Pounds/tC & 2020 & 2030 \\
\hline Low & 55 & 65 \\
\hline Central & 90 & 100 \\
\hline High & 160 & 170 \\
\hline
\end{tabular}

Source: Paul Watkiss Associates, UK.

\section{RESULT AND DISCUSSION}

An analysis of figures from LCOE table (Table 2) shows that in 2025,

- Levellized cost for coal $\quad=\$ 101 / \mathrm{MWh}$

- Levellized cost for solar PV $=\$ 456 / \mathrm{MWh}$

Also, from Table 3, the social cost of carbon for the year 2025 can be estimated as 95 pounds/ tonnage of carbon (using the central estimate)

Assuming an exchange rate of 1 British pounds $=1.242$ U.S. dollars

- $\quad$ The estimate for Social Cost of Carbon (central) $=95 \times 1.242=\$ 118 / \mathrm{tC}$

Also, assuming an Emission factor $=0.000744$ metric tons CO2/KWh of electricity (US EPA, 2017).

- The Social cost of Carbon per MW = 0.000744 X $1000 \times 118=\$ 83 / \mathrm{MW}$

Hence new design cost for the Coal power plant becomes $101+88=\$ 189 / \mathrm{MW}$.

\subsection{DISCUSSION}

From the result above, by considering the social cost of emissions, there is an additional $\$ 83 / \mathrm{MW}$ for the fossils plant and this is for $\mathrm{CO} 2$ emissions only not considering other gases and compounds that are also emitted while using fossils plants. Also note that this result is arrived at by using Solar PV plant which from Table 2, has the highest levellized cost. Cost analysis using other renewable energy technologies resulted in reduced levellized cost estimates and by considering the cost of carbon for such technologies investments in renewables becomes even more viable. For instance, IRENA working paper series (2012) puts the levellized cost for large and small hydro power plants at a maximum of 190 and 270 USD per MW respectively, indicating a closer match to the 184 USD per MW cost for Coal power plant in the result above.

Also, with accurate weather forecasts and the right technologies, the problem of intermittency and lower capacity utilization is being curtailed to an appreciable extent. Renewable energy resources power plant in the world today possesses inherent ability to guarantee reduction in $\mathrm{CO} 2$ emissions, guarantee security of energy supply and improved access to the resource. Other spill over benefits such as employment opportunities generation (due to its decentralized nature) and reduced dependence on fossils (thereby reducing fossils prices) also supports the clamor for renewable energy development.

\section{CONCLUSIONS AND RECOMMENDATIONS}

In Nigeria today, the present energy shortage drives the point that there is need for increased generation capacity and renewable energy sources presents a means of achieving this aim. Renewable energy sources will bridge the gap in the Nigerian energy sector by adding clean and cost-effective electrical power generation to the current generation capacity in order to meet the base load demand and subsequently the peak demand.

The planned hydro power plant construction in Mambilla plateau with a generation capacity of 3050MW in Gembu, Taraba state has the potential to reduce the current supply gap if completed. Government needs to show 
more commitment in enhancing the power generation capacity by embarking on more time bound renewable energy projects. These projects, backed up by well thought out regulatory policies would serve as framework to all players in the sector. This will also boost the confidence of private investors. Creation of suitable and stable investment climate can also help to overcome any other kinds of barriers to developing renewable energy projects.

According to Gauss and Prelas (2011), over 145 countries have introduced regulations which include auctions, feed-in tariffs, net metering, public financing, subsidies and fiscal incentives and this has ensured more than 10 times growth of renewable energy projects globally. Furthermore, the introduction of Renewable energy master plan (REMP) is a very commendable step. REMP is a policy being implemented by Nigeria's Federal Ministry of Environment that aims to increase the contribution of renewable energy to account for $10 \%$ of Nigeria's total energy consumption by 2025 (IEA, 2014). However, there is the need for the will power to judiciously implement its provisions in order to achieve its purpose.

Finally, the Establishment of a 213 billion Nigeria Electricity market stabilization facility by Central Bank of Nigeria to provide operators in the power sector with soft loan to improve their capacity, can provide financial access to private individuals who can engage in small off-grid renewable energy development projects that can supply electricity to segmented demands such as schools, farms etc. These policies should be further encouraged and more budgetary allocations made from time to time in favor of renewable energy power generation projects to further close the power supply gap and meet global electricity supply standards.

\section{SOURCES OF FUNDING}

This research received no specific grant from any funding agency in the public, commercial, or not-for-profit sectors.

\section{CONFLICT OF INTEREST}

The author have declared that no competing interests exist.

\section{ACKNOWLEDGMENT}

None.

\section{REFERENCES}

[1] CarbonBrief UK (2016) Online, Accessed; January 12, 2017 at www.nigeriaelectricityhub.com.

[2] Diji C (2013) "Electricity Production from Biomass in Nigeria: Options, Prospects and Challenges", Paper presented to International Journal of Engineering and Applied Sciences, vol. 3, number 4.

[3] Environmental Protection Agency (2017) "Greenhouse Gases Equivalencies Calculator - Calculations and References" (online) Accessed; 31/12/2017, at https://www.epa.gov/energy/greenhouse-gasesequivalencies-calculator-calculations-and-references.

[4] Frank Sensful; Mario Ragwitz; Massimo Genoese (2007), "The Merit Order effect: A detailed analysis of the price effect of renewable electricity generation on spot market prices in Germany", presented to Fraunhofer Institute for Systems and Innovation research, No S7/2007.

[5] Geoffrey Heal (2009), "The Economics of Renewable Energy", NBER working paper series (15081), online, Accessed; 10/03/17 at www.nber.org/papers/w15081

[6] Globe Power Services Limited (2016), "Solar Power" (online) Accessed; 31/01/2017 at http//nationalmirroronline.net.

[7] Gosh, T. and Prelas, A. (2009) "Energy Resources and Systems”, Springer Science + Business media, BV, Vol 1, e-ISBN: 978-90-481-2383-4.

[8] Gosh, T. and Prelas, A. (2011) "Energy Resources and Systems”, Springer Dordrecht Heidelberg London New York, BV, Vol 2, e-ISBN 978-94-007-1402-1.

[9] International Energy Agency (2014) Online, Accessed; 15/02/2017 at https://www.iea.org/policiesandmeasures/pams/nigeria/ 
How Could Renewable Energy Resources Bridge the Gap in Nigeria's Energy Sector?

[10] International Renewable Energy Agency (2012) "Renewable energy technologies: Cost analysis series Hydropower", Vol 1, Issue 3/5, (online) Accessed; at https://www.irena.org/documentdownloads/publications/re_technologies_cost_analysis-hydropower.pdf $31 / 12 / 2017$.

[11] Ministry of New and Renewable Energy (MNRE), "Biomass Power and Cogeneration Programme" (Online), Accessed; 14/03/2017 at www.mnre.gov.in/schemes/grid-connected/biomass-powercogen

[12] Nigerian Electricity Regulatory Commission (2016)," Weekly Energy Watch" (online), Assesssed; 31/01/2017 at www.nercng.org

[13] Paul Watkiss Associates, "Cost of Carbon”, 37321411.pdf, (online), Accessed; 17/03/2017 at www.oecd.org/env/

[14] Renewables 2007 Global Status Report (2008), World Watch Institute, Washinton DC, Page 41 (online) Accessed; 02/02/2017 at www.worldwatch.org/node/

[15] Sambo A. S. (2006), "Renewable energy electricity in Nigeria: the way forward", Paper presented to the Renewable Electricity Policy conference held at Shehu Musa Yar adua center Abuja. PP. 11-12.

[16] Simonyan, K. and Fasina, O. (2013), "Biomass Resources and Bio-energy potentials in Nigeria", Paper presented to the African Journal of Agricultural Research, Vol. 8(40), pp. 4975-4989.

[17] Subhes Bhattacharyya (2011) "Energy Economics, Concepts, Issues, Market and Governance", Springer London Dordrecht Heidelberg New York, e-ISBN 978-0-85729-268-1.

[18] Trading Economics (2017), "Economic Indicators Nigeria" (online), Accessed 31/01/2017 at www.tradingeconomics.com.

[19] US Energy Information Administration (2014), "Nigeria Overview", (online), Accessed 31/01/2017 at https://www.eia.gov/beta/international/analysis.cfm?iso=NGA

[20] World Bank (2017), "Pricing Carbon", (online) Accessed; 31/01/2017, at www.worldbank.org/en/programs/pricingcarbon

[21] Zarma Ismaila (2006), "Hydro power resources in Nigeria", being a country position paper presented at 2nd 'Hydro power for today' conference, International Center on Small Hydro Power (IC-SHP), Hangzhou, China. 